\title{
Effects of Increasing Levels of Refined Cornstarch in the Diet of Lactating Dairy Cows on Performance and Ruminal pH
}

\author{
K. M. Krause, ${ }^{*}$ D. K. Combs, ${ }^{*}$ and K. A. Beauchemin† \\ ${ }^{*}$ Department of Dairy Science, \\ University of Wisconsin, Madison 53706 \\ †Research Centre, Agriculture and Agri-Food Canada, \\ Lethbridge, AB, Canada T1J 4B1
}

\begin{abstract}
Our study investigated the effect of a linear increase in level of ruminally fermentable carbohydrate, at a constant level of dietary starch and fiber, on performance, microbial $\mathrm{N}$ yield, chewing activity, and ruminal $\mathrm{pH}$ of midlactation dairy cows. Eight cows (53 DIM) were assigned to four treatments in a double $4 \times 4$ Latin square. Diets consisted of increasing levels of refined cornstarch $(0,5.9,11.9$, and $17.9 \%$ of diet dry matter $)$ replacing dry cracked, shelled corn so that increasing amounts of dietary starch originated from refined cornstarch. Corn gluten feed was used to balance diets for similar NDF content. The four diets averaged 17.9\% $\mathrm{CP}, 27.2 \% \mathrm{NDF}, 18.7 \% \mathrm{ADF}$, and $31.1 \%$ starch (dry matter basis). Diets were fed for ad libitum intake and had a forage to concentrate ratio of 40:60. Forage was coarsely chopped (13.7 mm mean particle size) alfalfa silage. Daily dry matter intake averaged $26.0 \mathrm{~kg}$ and tended $(P=0.08)$ to increase quadratically with increasing level of refined cornstarch. Milk production averaged $38.9 \mathrm{~kg} / \mathrm{d}$ and milk fat percentage tended $(P=$ $0.08)$ to decrease linearly, whereas percentage of protein increased quadratically, with increasing level of refined cornstarch. Yield of components and energy corrected milk was similar across diets. Total tract digestibility of starch increased linearly from $85.1 \%$ to $92.4 \%$ with increasing level of refined cornstarch. Microbial yield was unaffected by diet and averaged $371.1 \mathrm{~g} \mathrm{~N} /$ d. Time spent eating decreased linearly from 329 to 308 $\mathrm{min} / \mathrm{d}$ when level of refined cornstarch was increased, but rumination time was unaffected. Ruminal concentration and proportion of acetate decreased linearly while concentration and proportion of propionate increased linearly with increasing level of refined cornstarch. Mean ruminal pH, time spent below pH 5.8 (h), and area below $\mathrm{pH} 5.8(\mathrm{~h} \times \mathrm{pH}$ units/d) were unaffected
\end{abstract}

Received August 3, 2002.

Accepted October 22, 2002.

Corresponding author: D. K. Combs; e-mail: dkcombs@facstaff. wisc.edu.

by level of refined cornstarch and averaged 5.97, 8.4, and 2.9 , respectively.

Increasing the level of carbohydrates fermented in the rumen by replacing dry cracked corn with refined cornstarch (up to $57 \%$ of dietary starch) did not compromise rumen fermentation or affect performance of midlactation dairy cows.

(Key words: milk production, ruminally fermentable carbohydrate, refined cornstarch, ruminal $\mathrm{pH}$ )

Abbreviation key: CS0 $=0 \%$ refined cornstarch, CS6 $=5.9 \%$ refined cornstarch, $\mathbf{C S 1 2}=11.9 \%$ refined cornstarch, $\mathbf{C S 1 8}=17.9 \%$ refined cornstarch, $\mathbf{E C M}=$ energy corrected milk, ERD = effective rumen degradability .

\section{INTRODUCTION}

Corn grain is a dominant feed in North America. Processing of the corn grain is imperative to maximize its utilization by dairy cattle. Physical processing techniques such as grinding or rolling increases total tract digestibility of corn grain (Firkins et al., 2001). Rate of starch digestion in the rumen is increased by breaking the outer coat of the kernel and allowing access to the endosperm of ruminal microorganisms and enzymes (McAllister et al., 1990), thereby increasing the rate and extent of VFA production.

Excess fermentation of starch to VFA in the rumen may overwhelm the buffering and absorptive capacity of the cow, leading to reductions in ruminal $\mathrm{pH}$. A decrease in ruminal $\mathrm{pH}$ can decrease appetite (Britton and Stock, 1987), fiber digestion (Mould et al., 1983) and microbial yield (Strobel and Russell, 1986), leading to decreased energy intake and production. Several studies have shown that dry matter intake (DMI) decreased when more rapidly available starch sources were fed (McCarthy et al., 1989; Moore et al., 1992; Aldrich et al., 1993), but we found no effect on DMI when ground high moisture corn replaced dry cracked corn in diets fed to midlactation cows in a previous study (Krause et al., 2002a). Conversely, we found that increasing ruminal fermentability of corn decreased mean ruminal $\mathrm{pH}$, and increased hours spent below $\mathrm{pH}$ 
5.8 and area below pH 5.8 (Krause et al., 2002b). Others have found only minor differences in ruminal $\mathrm{pH}$ resulting from corn processing (Knowlton et al., 1996; 1998; Crocker et al., 1998). Callison et al. (2001) reported that mean ruminal $\mathrm{pH}$, measured at four time points after feeding, responded quadratically when fine-, medium-, and coarse-ground corn was fed to lactating dairy cows, but lactation performance was unaffected. To our knowledge, no other studies have investigated the effect of increasing the proportion of ruminally fermentable carbohydrates from corn grain on ruminal $\mathrm{pH}$ and fermentation. The objective of the current study was to investigate the effect of a linear increase in level of ruminally fermentable carbohydrate, at a constant level of dietary starch and fiber, on performance, microbial yield, chewing activity and ruminal $\mathrm{pH}$ of midlactation dairy cows.

\section{MATERIALS AND METHODS}

\section{Cows and Diets}

Eight multiparous Holstein cows were assigned randomly to one of two squares in a double $4 \times 4$ Latin square. Cows were fitted with ruminal cannulas and averaged $53 \pm 16$ (mean \pm SD) DIM at the start of the experiment. Average BW was $658 \pm 33$ (mean $\pm \mathrm{SD}$ ) kg at the beginning of the experiment and $719 \pm 44$ (mean $\pm \mathrm{SD}) \mathrm{kg}$ at the end of the experiment. Experimental periods were $23 \mathrm{~d}$ in duration ( $10 \mathrm{~d}$ of treatment adaptation and $13 \mathrm{~d}$ of data collection). Rumen contents were switched between cows at the end of each period to facilitate adjustment to the new diet fed. Treatments consisted of four diets with increasing levels of refined cornstarch replacing dry cracked shelled corn. The refined cornstarch was feed grade cornstarch (Cargill Inc., $\mathrm{MN}$, product number 1100) produced by wet milling (mean particle size of 15 microns and density of $1.3 \mathrm{~g} /$ $\mathrm{ml})$. Mean geometric particle size of dry cracked corn was $1.54 \pm 0.06 \mathrm{~mm}$ (mean $\pm \mathrm{SD}$ ) when determined by dry-sieving (ASAE, 1995). Diagonal diameters of openings in screens were: $4.75,2.36,1.18,0.60,0.30,0.15$, and $0.063 \mathrm{~mm}$. Distribution of particles, as a percent of total mass, on the seven screens and the pan, respectively, were: $13.4,40.9,23.6,7.1,3.3,2.5,8.3$, and 0.8 . Diets were formulated to contain the same amount of starch from corn, but with increasing amounts of starch originating from refined cornstarch. Corn gluten feed was added in increasing amounts with refined cornstarch in order to keep the four diets equal in NDF. Refined cornstarch was assumed to be $100 \%$ ruminally digestible, whereas the starch in dry cracked corn was assumed to have a ruminally digestibility of $65 \%$ (Nocek and Tamminga, 1991). By replacing dry cracked corn with refined cornstarch the amount of carbohydrates
Table 1. Composition and nutrient content of dietary treatments.

\begin{tabular}{lcccc}
\hline & \multicolumn{4}{c}{ Treatments $^{1}$} \\
\cline { 2 - 5 } & CS0 & CS6 & CS12 & CS18 \\
\hline Feedstuff, \% of DM & & & & \\
Alfalfa silage & & 39.1 & 39.7 & 39.8 \\
Dry cracked shelled corn $^{2}$ & 39.1 & 31.0 & 22.7 & 14.2 \\
Refined cornstarch $^{3}$ & 0 & 5.9 & 11.9 & 17.9 \\
Corn gluten feed & 0 & 1.6 & 3.6 & 6.0 \\
Corn gluten meal & 2.0 & 2.0 & 2.0 & 2.0 \\
Wheat middlings & 9.4 & 9.5 & 9.5 & 9.5 \\
Soybean, whole roasted & 7.8 & 7.9 & 7.9 & 8.0 \\
Soybean meal, 44\% & 1.2 & 1.2 & 1.2 & 1.2 \\
Blood meal & 0.6 & 0.6 & 0.6 & 0.6 \\
Calcium carbonate & 0.20 & 0.20 & 0.20 & 0.20 \\
Dicalcium phosphate & 0.16 & 0.16 & 0.16 & 0.16 \\
ADE vitamin vix & 0.16 & 0.16 & 0.16 & 0.16 \\
Salt and trace mineral mix & 0.40 & 0.40 & 0.40 & 0.40 \\
NE ${ }^{4}$, Mcal/kg DM & 1.61 & 1.59 & 1.59 & 1.59 \\
DM, \% & 64.7 & 66.1 & 66.0 & 64.5 \\
OM, \% of DM & 87.3 & 87.6 & 87.4 & 87.2 \\
CP, \% of DM & 18.4 & 18.0 & 17.9 & 17.4 \\
NDF, \% of DM & 28.0 & 26.9 & 27.1 & 26.7 \\
ADF, \% of DM & 19.3 & 18.5 & 18.5 & 18.6 \\
Starch, \% of DM & 29.2 & 31.1 & 32.8 & 31.3 \\
NFC ${ }^{5}$ \% of DM & 36.5 & 38.6 & 38.5 & 39.5 \\
\hline
\end{tabular}

${ }^{1}$ Treatments: $\mathrm{CS} 0=0 \%$ refined cornstarch; $\mathrm{CS} 6=5.9 \%$ refined cornstarch; $\mathrm{CS} 12=11.9 \%$ refined cornstarch; $\mathrm{CS} 18=17.9 \%$ refined cornstarch.

${ }^{2}$ Alfalfa silage contained $49.1 \% \mathrm{DM}$, and $19.5 \% \mathrm{CP}, 45.6 \% \mathrm{NDF}$ and $37.7 \% \mathrm{ADF}$ on a DM basis.

${ }^{3}$ Refined cornstarch contained $90 \%$ DM, 100\% OM, 100\% starch, $0 \% \mathrm{CP}$ and $0 \% \mathrm{NDF}$ on a DM basis.

${ }^{4}$ Based on tabular values (NRC, 2001). Refined cornstarch was assumed to contain $100 \%$ TDN on a DM basis and $\mathrm{NE}_{\mathrm{L}}$ content was calculated using the equation: $\mathrm{NE}_{\mathrm{L}}, \mathrm{Mcal} / \mathrm{lb} \mathrm{DM}=(\mathrm{TDN}, \%$ of $\mathrm{DM} \times$ $0.01114)-0.054$.

${ }^{5} \mathrm{NFC}=$ non-fiber carbohydrates, calculated using tabular values for ether extract content of feeds (NRC, 2001).

fermented in the rumen could be increased while total non-fiber carbohydrates were kept constant. The four diets contained 0\% refined cornstarch (CS0), 5.9\% (CS6), $11.9 \%$ (CS12), and $17.9 \%(\mathbf{C S 1 8})$ on a dry matter basis.

First cut wilted alfalfa silage harvested at the mid bloom stage of maturity was the sole source of forage. The forage was harvested with a Gehl forage chopper (model 865; Gehl Implement, West Bend, WI) with a head (model 1210) adjusted to cut forage at 1.9-cm theoretical length of cut. Forage was ensiled in a $3.7 \mathrm{~m} \times$ $12.2 \mathrm{~m}$ concrete stave silo. Mean geometric particle size of alfalfa silage determined by dry-sieving was $13.7 \pm$ $1.6 \mathrm{~mm}$ (ASAE standard S424, 1988). Diagonal diameters of openings in screens were: $26.90,18.00,8.98,5.61$, and $1.65 \mathrm{~mm}$. Distribution of particles, as a percent of total mass, on the five screens and the pan, respectively, were: $17.4,27.1,31.5,10.2,10.7$, and 3.1. All diets were formulated to meet or exceed the requirements of a 600 $\mathrm{kg}$ multiparous cow producing $45 \mathrm{~kg}$ milk/d according to NRC (1989). Diet formulations are given in Table 1. 
Diets were fed as total mixed rations (TMR) with a ratio of forage to concentrate of 40:60 (DM basis). Cows were fed for ad libitum intake (10\% refusals) and feed was offered twice daily at $0700 \mathrm{~h}$ and $1900 \mathrm{~h}$ in equal portions. Cows had free access to water. Intake and milk production were recorded daily throughout the experiment, and feed and orts samples were taken twice weekly. Dry matters $\left(60^{\circ} \mathrm{C}\right)$ of feed components were determined weekly and diets were adjusted to account for changes in DM content.

Cows were cared for according to guidelines of the Research Animal and Resource Committee of the University of Wisconsin-Madison and all experimental procedures performed on the animals were approved. Cows were housed in tie stalls fitted with rubber mattresses and bedded with wood shavings and were milked twice daily at $0300 \mathrm{~h}$ and $1500 \mathrm{~h}$ in a milking parlor. Cows were turned outside on a dry-lot for 1 to $2 \mathrm{~h}$ daily after being milked, except on days when total urine output was measured. Milk was sampled on 3 consecutive d during the $\mathrm{pm}$ and am milkings during each period and analyzed for milk components using near infrared reflectance spectroscopy (AgSource, Menomonie, WI). Milk composition was corrected for differences in milk volume between am and pm milkings. Yield of energy corrected milk (ECM) was calculated from the energy output in milk using the equation by Tyrrell and Reid $(1965)\left(\mathrm{NE}_{\mathrm{L}}, \mathrm{Mcal} / \mathrm{d}=\right.$ milk yield, $\mathrm{kg} / \mathrm{d} \times((0.0929 \times$ percent fat $)+(0.0563 \times$ percent true protein $)+(0.0395 \times$ percent lactose)), divided by the assumed energy content of $4 \% \mathrm{FCM}$ of $0.749 \mathrm{NE}_{\mathrm{L}}, \mathrm{Mcal} / \mathrm{kg}$.

\section{Feed Analysis}

Samples of all feeds, diets, and orts were collected on three occasions during each data collection period. Dried composite samples were ground to pass a 1-mm screen (Wiley mill, Arthur H. Thomas, Philadelphia, PA). Analytical DM content of feeds was determined by oven drying at $100^{\circ} \mathrm{C}$ overnight; $\mathrm{OM}$ was determined by ashing, and $\mathrm{CP}$ was determined by the micro-Kjeldahl method (AOAC, 1990). The NDF fraction was determined using $\alpha$-amylase (Sigma no. A3306: Sigma Chemical Co., St. Louis, MO), sodium sulfite and was corrected for ash content according to Mertens (1999) adapted for Ankom ${ }^{200}$ Fiber Analyzer (Ankom Technology, Fairport, NY). Acid detergent fiber was determined using the procedure described by Goering and Van Soest (1970), adapted for Ankom ${ }^{200}$ Fiber Analyzer. Starch was determined using $\alpha$-amylase and amyloglucosidase as described by Bal et al. (2000).

\section{Digestibility}

Lanthanum oxide in solution $(0.2 \mathrm{~g} / \mathrm{ml})$ was used as a marker to measure total tract digestibility (Hartnell and Satter, 1979) and was dosed through the rumen cannula at 12-h intervals for the last $14 \mathrm{~d}$ of each period to provide $0.8 \mathrm{~g}$ of La per cow per d. Seventeen fecal samples were collected at different times of the day during a 5-d interval concurrent with fecal sampling for rate of passage measurements. Sampling times differed such that the entire 24-h day was represented to account for possible diurnal variation. Fecal samples were dried, ground to pass a 1-mm screen, pooled by period for each cow and dry-ashed at $550^{\circ} \mathrm{C}$ for $16 \mathrm{~h}$. Concentrations of La were determined by direct current plasma emission spectroscopy (Spectra Metrics, Inc., subsidiary of Beckman Instruments, Inc., Andover, MA) (Combs and Satter, 1992). Apparent total tract nutrient digestibilities were calculated from fecal La concentration and nutrient concentrations in diets fed, orts and feces using the following equation: Apparent digestibility $=100-\left(100 \times M_{d} / M_{f} \times N_{f} / N_{d}\right)$, where $M_{d}=$ concentration of the marker in the diet, $\mathrm{M}_{\mathrm{f}}=$ concentration of the marker in the feces, $\mathrm{N}_{\mathrm{f}}=$ concentration of the nutrient in the feces, and $\mathrm{N}_{\mathrm{d}}=$ concentration of the nutrient in the diet.

\section{In Sacco Measurements}

Ruminal degradation of the alfalfa silage was measured using in situ bags made of dacron polyester cloth with a pore size of $52 \pm 5 \mu \mathrm{m}$ (mean $\pm \mathrm{SD}$ ). Approximately $5 \mathrm{~g}$ of sample dried at $60^{\circ} \mathrm{C}$ for $48 \mathrm{~h}$ and ground through a $2 \mathrm{~mm}$ screen was weighed into bags. Before insertion into the rumen bags were soaked in warm water for $10 \mathrm{~min}$ to simulate the addition of saliva. Bags were placed in large mesh retaining sacs before being incubated ruminally for $0,6,12,24,48,72,96$, and $120 \mathrm{~h}$. All time points were done in duplicate. After removal from the rumen, bags were washed under cold, running tap water, and then machine-washed according to the procedure by Cherney et al. (1990). The $0 \mathrm{~h}$ time point bags were not placed in the rumen, but were subject to the same washing procedure. Bags were dried at $60^{\circ} \mathrm{C}$ for $48 \mathrm{~h}$.

The kinetics of DM, NDF, and ADF disappearance in sacco were estimated using the PROC NLIN procedure of SAS (1998). For each cow and period the following model (McDonald, 1981) was fitted to the percentage of disappearance:

$$
y=a+b\left(1-e^{-k d(t-L)}\right) \text { for } t>L
$$

where $\mathrm{a}=$ soluble fraction $(\%) ; \mathrm{b}=$ slowly digestible fraction $(\%) ; \mathrm{k}_{\mathrm{d}}=$ fractional rate of disappearance $(\%$ $\left.\mathrm{h}^{-1}\right) ; \mathrm{L}=$ lag time (h); and $\mathrm{t}=$ incubation time $(\mathrm{h})$. The indigestible fraction, c, was calculated by difference. 


\section{Rate of Passage}

Chromium-mordanted fiber was prepared as described by Udén et al. (1980) and used as a marker for solid passage rates. Chromium-mordanted fiber was prepared by mordanting wheat straw NDF ground through a $6-\mathrm{mm}$ screen using a Wiley mill. The marker was placed in the rumen at the time of the morning feeding and no attempt was made to manually mix the marker with rumen contents. Fecal grab samples were taken at $0,6,10,14,18,22,26,30,36,42,48,54,60$, $72,84,96$ and 120 after dosing to determine the rate of passage. Samples were dry-ashed and fecal marker concentrations of $\mathrm{Cr}$ were determined by direct current plasma emission spectroscopy (Spectra Metrics, Inc., subsidiary of Beckman Instruments, Inc., Andover, MA; Combs and Satter, 1992).

Fecal $\mathrm{Cr}$ excretion curves were fitted to the doublecompartment model represented by two exponential constants and a time delay (Grovum and Williams, 1973):

$$
\begin{aligned}
& \mathrm{Y}=\mathrm{Ae}^{-\mathrm{k} 1(\mathrm{t}-\mathrm{TT})}-\mathrm{Ae}^{-\mathrm{k} 2(\mathrm{t}-\mathrm{TT})}, \mathrm{k} 1<\mathrm{k} 2 \text { for } \mathrm{t} \geq \mathrm{TT} \\
& \mathrm{Y}=0 \text { for } \mathrm{t}<\mathrm{TT}
\end{aligned}
$$

where $\mathrm{Y}=$ marker concentration $(\mathrm{ppm}) ; \mathrm{A}=$ scale parameter; $\mathrm{k} 1=$ rumen turnover rate $\left(\% \mathrm{~h}^{-1}\right) ; \mathrm{k} 2=$ lower digestive tract turnover rate $\left(\% \mathrm{~h}^{-1}=\right.$ sampling time post dosing (h); TT = transit time. Total mean retention time in the digestive tract was calculated as the sum of retention in the rumen $(1 / \mathrm{k} 1)$ and in the lower digestive tract ( 1 / k2) plus the transit time (TT). Data were analyzed by non-linear regression using the NLIN (iterative Marquardt method) procedure of SAS (1998).

\section{Microbial Protein Synthesis}

Microbial protein synthesis was not measured directly. Instead, the urinary excretion of the purine derivatives allatoin and uric acid were used as an estimate of microbial $\mathrm{N}$ flow to the duodenum (Vagnoni et al., 1997). On 3 consecutive $d$ in each experimental period total urine was collected using indwelling catheters. Containers with $500 \mathrm{ml}$ of $1.5 \mathrm{~N} \mathrm{H}_{2} \mathrm{SO}_{4}$ were attached to each cow and output of urine was measured twice daily. After recording the volume of urine excreted, acidified urine was mixed and samples $(20 \mathrm{ml})$ were taken, diluted to $100 \mathrm{ml}$ with tap water and frozen $\left(-20^{\circ} \mathrm{C}\right)$ for later analysis. Concentration of allantoin in urine was determined colorimetrically using the method described by Chen and Gomes (1992), however, $1 \mathrm{M} \mathrm{HCl}$ was used instead of $0.5 \mathrm{M} \mathrm{HCl}$ in the assay in order to keep $\mathrm{pH}$ below 3. Uric acid in urine was determined colorimetrically using a diagnostic uric acid reagent (Procedure No. 685, Sigma Diagnostics, St. Louis, MO). For the uric acid assay $2 \mathrm{ml}$ of reagent was used with $50 \mu$ l of urine diluted 25 times. Purine absorption and intestinal flow of microbial $\mathrm{N}$ was calculated using the assumptions and equations given by Chen and Gomes (1992). The quantitative relationship between absorption of microbial purines (X mmol/d), and excretion of purine derivatives in urine can be described by the following equation:

$$
\mathrm{Y}=0.85 \mathrm{X}+\left(0.0385 \mathrm{~W}^{0.75}\right),
$$

where $\mathrm{W}^{0.75}$ represents the metabolic body weight $(\mathrm{kg})$ of the animal. The slope of 0.85 represents the recovery of absorbed purines as purine derivatives in urine. The component within parenthesis represents the net endogenous contribution of purine derivatives to total excretion after correction for the utilization of microbial purines by the animal. The following factors were used for the calculation of intestinal flow of microbial $\mathrm{N}$ ( $\mathrm{g}$ $\mathrm{N} / \mathrm{d}$ ) from the microbial purines absorbed (X mmol/d): digestibility of microbial purines was assumed to be 0.83 ; the $\mathrm{N}$ content of purines was $70 \mathrm{mg} \mathrm{N} / \mathrm{mmol}$; and the ratio of purine-N:total $\mathrm{N}$ in mixed rumen microbes was taken as 11.6:100. Thus microbial $\mathrm{N}$ was calculated as:

$$
\begin{array}{r}
\text { Microbial N supply }(\mathrm{g} / \mathrm{d})= \\
\begin{array}{r}
(\mathrm{X} \times 70) /(0.83 \times 0.116 \times 1000) \\
=0.727 \times \mathrm{X}
\end{array}
\end{array}
$$

This assumes that the purine:protein ratio in mixed rumen microbes was unchanged by dietary treatment.

\section{Ruminal pH and VFA Concentrations}

Ruminal $\mathrm{pH}$ was measured continuously for $3 \mathrm{~d}$ using an industrial electrode (Epoxy body sealed combination pH electrode, no. 970061, Sensorex Corp., Garden Grove, CA) placed in the ventral sac of the rumen. A weight was attached to the electrode to prevent it from shifting in the rumen. Ruminal $\mathrm{pH}$ was recorded every minute and downloaded to a computer. Data collection was interrupted twice daily at time of milking. Time during which $\mathrm{pH}$ was below 5.8 and the area under $\mathrm{pH}$ 5.8 were calculated. The area was calculated by adding the absolute value of negative deviations in $\mathrm{pH}$ from $\mathrm{pH} 5.8$ for each minute within a day. The number was divided by 60 in order to get the units $\mathrm{h} \times \mathrm{pH}$ units per day. Because of the substantial size of the data set, $\mathrm{pH}$ values were averaged by hour before being analyzed as repeated measurements. Using this new data set, mean $\mathrm{pH}$, lowest $\mathrm{pH}$ for each cow, and time to nadir were recorded. 
Ruminal fluid was sampled 0,4 , and $8 \mathrm{~h}$ after the morning feeding on two days. Approximately $100 \mathrm{ml}$ of ruminal fluid was obtained from the anterior dorsal, anterior ventral, medial ventral, posterior dorsal, and posterior ventral locations within the rumen, composited by cow, and strained through two layers of cheesecloth. Samples of $10 \mathrm{ml}$ were acidified with $0.5 \mathrm{ml}$ of $\mathrm{H}_{2} \mathrm{SO}_{4}$ and frozen for later analysis for VFA. These samples were prepared for analysis as follows: 1) sample tubes were thawed and centrifuged at $2000 \times g, 4^{\circ} \mathrm{C}$ for $15 \mathrm{~min}, 2)$ supernatant ( $1 \mathrm{ml}$ ) was transferred into a microfuge tube, $0.2 \mathrm{ml}$ of $25 \%$ metaphosphoric acid was added, and the mixture was vortexed before incubating at room temperature for $30 \mathrm{~min}, 3$ ) samples were centrifuged at $10,000 \times g$ for $3 \mathrm{~min}$, and 4) supernatant was transferred into a GLC sample vial for analysis by GLC (Perkin Elmer Autosystem, Perkin Elmer Corp., Norwalk, CT) with GP $10 \%$ SP- $1200 / 1 \% \mathrm{H}_{3} \mathrm{PO}_{4}$ on $80 /$ 100 Chromasorb WAW column packing (Supelco, Bellefonte, PA).

\section{Chewing Activities}

Eating and rumination behaviors were monitored visually for a $24-\mathrm{h}$ period during the days of ruminal $\mathrm{pH}$ monitoring and for another $24-\mathrm{h}$ period during the data collection period. Eating and ruminating activities were noted every $5 \mathrm{~min}$, and each activity was assumed to persist for the entire 5-min interval. A meal was defined as at least one observation of eating activity occurring after at least $20 \mathrm{~min}$ without eating activity (Wangsness et al., 1976). To estimate the time spent eating per $\mathrm{kg}$ of DMI, the actual intake for that day was used. A period of rumination was defined as at least $5 \mathrm{~min}$ of rumination occurring after at least $5 \mathrm{~min}$ without ruminating activity. When estimating the number of rumination periods per $\mathrm{kg}$ of DMI, or time spent ruminating per $\mathrm{kg}$ of NDF intake, the average daily intake measured in that period was used because time spent ruminating was assumed to reflect the DMI of the previous days. Total time spent chewing was calculated as the total time spent eating and ruminating.

\section{Statistical Analysis}

Data on all variables were analyzed using the mixed model procedure in SAS (SAS, 1998); period and diet were fixed effects in the model and period was used as a repeated measurement with first-order auto regressive co-variance structure. The random statement included square and cow within square. The model used for intake and production variables, digestibilities, chewing activities and purine derivative excretion data is shown below.

$$
\mathrm{Y}_{\mathrm{ijkl}}=\mu+\mathrm{S}_{\mathrm{i}}+\mathrm{C}_{\mathrm{j}(\mathrm{i})}+\mathrm{P}_{\mathrm{k}}+\mathrm{T}_{1}+\mathrm{e}_{\mathrm{ijk} \mathrm{k}}
$$

where $\mu$ = overall mean; $\mathrm{S}_{\mathrm{i}}=$ random effect of square (i $=1$ to 2$) ; \mathrm{C}_{\mathrm{j}(\mathrm{i})}=$ random effect of cow within square $(\mathrm{j}=$ 1 to 4); $P_{k}=$ fixed effect of period analyzed as repeated measurements $(\mathrm{k}=1$ to 4$) ; \mathrm{T}_{1}=$ fixed effect of diet ( $\mathrm{l}=$ 1 to 4); and $\mathrm{e}_{\mathrm{ijkl}}=$ random residual error, assumed to be normally distributed.

Ruminal VFA concentrations were analyzed using period, day, and hour as repeated measurements. The model with the best fit according to the Schwarz Baysian Criterion used a compound symmetry co-variance structure for period and day and a first-order auto regressive co-variance structure for hour. Ruminal VFA data were analyzed using the following model:

$$
\mathrm{Y}_{\mathrm{ijklmn}}=\mu+\mathrm{S}_{\mathrm{i}}+\mathrm{C}_{\mathrm{j}(\mathrm{i})}+\mathrm{P}_{\mathrm{k}}+\mathrm{T}_{\mathrm{l}}+\mathrm{D}_{\mathrm{m}}+\mathrm{H}_{\mathrm{n}}+\mathrm{e}_{\mathrm{ijklmn}},
$$

where $\mu$ = overall mean; $\mathrm{S}_{\mathrm{i}}=$ random effect of square (i $=1$ to 2$) ; \mathrm{C}_{\mathrm{j}(\mathrm{i})}=$ random effect of cow within square $(\mathrm{j}=$ 1 to 4$) ; P_{k}=$ fixed effect of period analyzed as repeated measurements $(\mathrm{k}=1$ to 4$) ; \mathrm{T}_{1}=$ fixed effect of diet ( $\mathrm{l}=$ 1 to 4); $D_{m}=$ fixed effect of day of sampling analyzed as repeated measurements ( $h=1$ to 2 ); $H_{n}=$ fixed effect of hours post feeding analyzed as repeated measurements $(p=1$ to 3$)$; and $e_{i j k l m n}=$ random residual error, assumed to be normally distributed. No significant interactions were found between day of sampling and main effects, hours post-feeding and main effects, or between day of sampling and hours post-feeding; therefore, these terms were left out of the model.

Before ruminal $\mathrm{pH}$ data were analyzed, $\mathrm{pH}$ values were averaged by hour in order to reduce the number of observations. One day of observations started at the first feeding at $7 \mathrm{~h}$ and ran until the next morning feeding. Even though cows were not fed restrictively, feeding at $0700 \mathrm{~h}$ and $1900 \mathrm{~h}$ resulted in a specific biphasic diurnal pattern in $\mathrm{pH}$. Therefore, feeding (first and second) was introduced as a variable in the model, creating a model with repeated measures on four levels: period, day, feeding, and hour post-feeding $(12 \mathrm{~h})$. The model with the best fit according to the Schwarz Baysian Criterion was a model using a compound symmetry covariance structure for period, day and feeding and a first-order auto regressive covariance structure for hours post feeding. Only main effects and two factor interactions were included in the fixed effects portion of the model, as three and four factor interactions appeared to be very small. The model was:

$$
\begin{aligned}
\mathrm{Y}_{\mathrm{ijklmno}}= & \mu+\mathrm{S}_{\mathrm{i}}+\mathrm{C}_{\mathrm{j}(\mathrm{i})}+\mathrm{P}_{\mathrm{k}}+\mathrm{T}_{\mathrm{l}}+\mathrm{D}_{\mathrm{m}}+(\mathrm{D} \times \mathrm{T})_{\mathrm{ml}}+ \\
& \mathrm{E}_{\mathrm{n}}+(\mathrm{E} \times \mathrm{T})_{\mathrm{nl}}+(\mathrm{D} \times \mathrm{E})_{\mathrm{mn}}+\mathrm{H}_{\mathrm{o}}+(\mathrm{H} \times \mathrm{T})_{\mathrm{ol}} \\
& +(\mathrm{H} \times \mathrm{D})_{\mathrm{om}}+(\mathrm{H} \times \mathrm{E})_{\mathrm{on}}+\mathrm{e}_{\mathrm{ijklmno}},
\end{aligned}
$$


Table 2. Effects of level of refined cornstarch on intake.

\begin{tabular}{|c|c|c|c|c|c|c|c|c|}
\hline \multirow[b]{2}{*}{ Intake, kg/d } & \multicolumn{4}{|c|}{ Treatments $^{1}$} & \multirow[b]{2}{*}{$\mathrm{SED}^{2}$} & \multicolumn{3}{|c|}{ Statistical significance ( $P$-value) } \\
\hline & CS0 & CS6 & CS12 & CS18 & & Linear & Quadratic & Cubic \\
\hline $\mathrm{DM}$ & 25.71 & 26.77 & 26.07 & 25.54 & 0.61 & 0.55 & 0.08 & 0.34 \\
\hline $\mathrm{OM}$ & 25.21 & 26.12 & 25.50 & 24.98 & 0.59 & 0.50 & 0.10 & 0.40 \\
\hline $\mathrm{NDF}$ & 7.36 & 7.26 & 7.56 & 7.00 & 0.36 & 0.37 & 0.79 & 0.29 \\
\hline Starch & 8.15 & 9.01 & 9.28 & 8.64 & 0.32 & 0.10 & 0.004 & 0.76 \\
\hline
\end{tabular}

${ }^{1}$ Treatments: $\mathrm{CS} 0=0 \%$ refined cornstarch; $\mathrm{CS} 6=5.9 \%$ refined cornstarch; $\mathrm{CS} 12=11.9 \%$ refined cornstarch; $\mathrm{CS} 18=17.9 \%$ refined cornstarch.

${ }^{2} \mathrm{SED}=$ standard error of difference.

where $\mu$ = overall mean; $\mathrm{S}_{\mathrm{i}}=$ random effect of square (i $=1$ to 2$) ; \mathrm{C}_{\mathrm{j}(\mathrm{i})}=$ random effect of cow within square $(\mathrm{j}=$ 1 to 4); $\mathrm{P}_{\mathrm{k}}=$ fixed effect of period analyzed as repeated measurements ( $\mathrm{k}=1$ to 4$) ; \mathrm{T}_{1}=$ fixed effect of diet $(\mathrm{l}=$ 1 to 4$) ; D_{m}=$ fixed effect of day of sampling analyzed as repeated measurements $(\mathrm{m}=1$ to 3$) ;(\mathrm{D} \times \mathrm{T})_{\mathrm{ml}}=$ fixed effect of interaction of $\mathrm{D}_{\mathrm{m}}$ and $\mathrm{T}_{1} ; \mathrm{E}_{\mathrm{n}}=$ fixed effect of feeding analyzed as repeated measurement $(\mathrm{n}=1$ to 2); $(\mathrm{E} \times \mathrm{T})_{\mathrm{nl}}=$ fixed effect of interaction of $\mathrm{E}_{\mathrm{n}}$ and $\mathrm{T}_{1}$; (D $\times \mathrm{E})_{\mathrm{mn}}=$ fixed effect of interaction of $\mathrm{D}_{\mathrm{m}}$ and $\mathrm{E}_{\mathrm{n}} ; \mathrm{H}_{\mathrm{o}}=$ fixed effect of hours post feeding analyzed as repeated measurements $(\mathrm{o}=1$ to 12$) ;(\mathrm{H} \times \mathrm{T})_{\mathrm{ol}}=$ fixed effect of interaction of $\mathrm{H}_{0}$ and $\mathrm{T}_{1} ;(\mathrm{H} \times \mathrm{D})_{\mathrm{om}}=$ fixed effect of interaction of $\mathrm{H}_{\mathrm{o}}$ and $\mathrm{D}_{\mathrm{m}} ;(\mathrm{H} \times \mathrm{E})_{\mathrm{on}}=$ fixed effect of interaction of $\mathrm{H}_{\mathrm{o}}$ and $\mathrm{E}_{\mathrm{n}}$; and $\mathrm{e}_{\mathrm{ijklmno}}=$ random residual error, assumed to be normally distributed.

Linear, quadratic, and cubic effects of increasing levels of refined cornstarch in diet were tested using orthogonal contrasts. Significance was declared at $P \leq$ 0.05 . A trend was considered to exist if $0.05<P \leq 0.10$. All means presented are least square means.

\section{RESULTS AND DISCUSSION}

\section{Intake}

Intakes of DM, OM, NDF, and starch are shown in Table 2. Intake of DM and OM (which averaged 26.0 and $25.5 \mathrm{~kg}$, respectively) was not affected by replacing dry cracked corn with refined cornstarch. However, increasing levels of refined cornstarch tended to affect $\mathrm{DM}$ and $\mathrm{OM}$ intake in a quadratic manner $(P=0.08$ and 0.10 , respectively) with intakes being highest for the 5.9\% level of refined cornstarch. DMI were higher than those reported by Krause et al. (2002a) where similar diets were fed, except that level of ruminally fermentable carbohydrates was increased by replacing dry corn with high moisture corn. Intake of NDF was not affected by diet and averaged $7.3 \mathrm{~kg} / \mathrm{d}$. Starch intake increased in a quadratic manner when level of refined cornstarch was increased and was highest for the diet with $11.9 \%$ refined cornstarch $(9.28 \mathrm{~kg} / \mathrm{d})$. This diet had the highest starch content even though diets were formulated to be similar in starch content.

\section{Milk Production}

Neither milk production $(38.9 \mathrm{~kg} / \mathrm{d})$ nor ECM $(35.2$ $\mathrm{kg} / \mathrm{d}$ ) was affected by diet (Table 3). However, milk production was numerically highest for the CS18 diet. A trend for a cubic relationship between level of refined cornstarch and production of ECM was found $(P=0.09)$, with production being highest for the diet with 5.9\% refined cornstarch and lowest for the diet with $11.9 \%$ refined cornstarch. Efficiency of milk production, expressed as ECM per kg DMI was not affected by diet.

Milk fat percentage tended $(P=0.08)$ to decrease linearly with increasing levels of refined cornstarch in the diet. This trend indicates that rumen fermentation was negatively affected by the high levels of dietary refined cornstarch. Fat yield was not affected by level of refined cornstarch despite the trend towards an effect on milk fat percentage. Percentage of milk protein increased in a quadratic manner when level of refined cornstarch increased, with the protein percentage being highest for the diets with intermediate levels of refined cornstarch. There was no difference in yield of protein between diets. Percentage of lactose and yield of lactose and other milk components were not affected by diet.

\section{Rate of Passage}

Passage of solids through the digestive tract was not affected by dietary treatments (Table 4). Rate of passage through the lower digestive tract, estimated from the ascending part of the excretion curve, averaged $10.5 \% / \mathrm{h}$. Transit time, rumen retention and mean total tract retention time were all unaffected by level of refined cornstarch in the diet. The lack of dietary effects on passage rates is not surprising, since DMI and time spent chewing was similar for all four diets.

\section{Digestibilities and Digestion Kinetics}

Total tract digestibility of DM and OM was not affected by diet and averaged $60.9 \%$ and $64.2 \%$, respec- 
Table 3. Effects of level of refined cornstarch on milk yield and milk composition.

\begin{tabular}{|c|c|c|c|c|c|c|c|c|}
\hline \multirow{2}{*}{$\begin{array}{l}\text { Dependent } \\
\text { variable }\end{array}$} & \multicolumn{4}{|c|}{ Treatments $^{1}$} & \multirow[b]{2}{*}{$\mathrm{SED}^{2}$} & \multicolumn{3}{|c|}{ Statistical significance ( $P$-value $)$} \\
\hline & CS0 & CS6 & CS12 & CS18 & & Linear & Quadratic & Cubic \\
\hline Milk, kg/d & 38.48 & 38.98 & 38.26 & 39.87 & 0.92 & 0.25 & 0.41 & 0.24 \\
\hline $\mathrm{ECM}, \mathrm{kg} / \mathrm{d}^{3}$ & 34.96 & 36.19 & 34.00 & 35.46 & 1.25 & 0.86 & 0.90 & 0.09 \\
\hline ECM/DMI & 1.37 & 1.38 & 1.31 & 1.42 & 0.1 & 0.66 & 0.28 & 0.19 \\
\hline Fat, $\%$ & 3.46 & 3.56 & 3.25 & 3.29 & 0.14 & 0.08 & 0.75 & 0.12 \\
\hline Fat yield, kg/d & 1.32 & 1.38 & 1.23 & 1.68 & 0.30 & 0.34 & 0.37 & 0.40 \\
\hline Protein, \% & 3.12 & 3.20 & 3.20 & 3.14 & 0.04 & 0.58 & 0.03 & 0.93 \\
\hline Protein yield, kg/d & 1.20 & 1.25 & 1.22 & 1.25 & 0.03 & 0.15 & 0.60 & 0.20 \\
\hline Lactose, \% & 4.87 & 4.87 & 4.87 & 4.87 & 0.03 & 0.93 & 0.95 & 0.86 \\
\hline Lactose yield, $\mathrm{kg} / \mathrm{d}$ & 1.87 & 1.90 & 1.87 & 1.94 & 0.05 & 0.30 & 0.47 & 0.32 \\
\hline $\mathrm{SNF}^{4}, \%$ & 8.81 & 7.99 & 8.90 & 8.83 & 0.63 & 0.63 & 0.41 & 0.19 \\
\hline SNF yield, kg/d & 3.39 & 3.46 & 3.18 & 3.52 & 0.18 & 0.87 & 0.32 & 0.11 \\
\hline
\end{tabular}

${ }^{1}$ Treatments: $\mathrm{CS} 0=0 \%$ refined cornstarch; $\mathrm{CS} 6=5.9 \%$ refined cornstarch; $\mathrm{CS} 12=11.9 \%$ refined cornstarch; CS18 $=17.9 \%$ refined cornstarch.

${ }^{2} \mathrm{SED}=$ standard error of difference.

${ }^{3} \mathrm{ECM}=$ energy corrected milk.

${ }^{4} \mathrm{SNF}=$ solids non-fat.

tively (Table 5). Total tract digestibility of NDF was not affected by level of refined cornstarch in the diet and averaged $37.8 \%$. Total tract digestibility of starch increased linearly from $85.1 \%$ to $92.4 \%$ with increasing levels of refined cornstarch in the diet. This increase indicates that refined cornstarch had a higher digestibility than starch from dry cracked corn as expected. Assuming that starch from feeds other than refined cornstarch had a total tract digestibility of $85.1 \%$ (based on the total tract digestibility of starch from diet CS0), the total tract digestibility of refined cornstarch can be calculated by difference. Using the total tract digestibility of starch from diet CS18, the total tract digestibility of starch from refined cornstarch would be $98 \%$. We expected that the majority of this starch was digested in the rumen, but this expectation is not supported by the rumen fermentation data. When van Vuuren et al. (1999) fed steam-flaked cornstarch to lactating cows, they found that $96 \%$ of the starch disappeared in the rumen. Replacing corn grain with refined cornstarch might have increased starch digestion in the lower gut. This could have some amino acid sparing effect, which could contribute to the increase in milk protein percentage observed with increasing levels of refined cornstarch in the diet. Also, an increase in glucose absorption could contribute to the numerically higher milk production for the CS18 diet.

Digestion kinetics of alfalfa silage DM was not affected by level of refined starch in the diet (Table 6), but lag tended $(P=0.07)$ to respond to level of refined cornstarch in a quadratic manner, with lag being highest for the CS6 diet. Effective rumen digestibility (ERD) averaged $59.4 \%$ across diets. Digestion kinetics of silage NDF is shown in Table 7. When level of refined cornstarch in the diet increased, the $b$ fraction of the silage NDF decreased linearly, and the $\mathrm{c}$ fraction tended $(P=$ 0.08 ) to increase linearly. Also, the rate of digestion of the silage NDF tended $(P=0.07)$ to respond to level

Table 4. Effects of level of refined cornstarch on rate of passage of solids.

\begin{tabular}{|c|c|c|c|c|c|c|c|c|}
\hline \multirow{2}{*}{$\begin{array}{l}\text { Dependent } \\
\text { variable }\end{array}$} & \multicolumn{4}{|c|}{ Treatments $^{1}$} & \multirow[b]{2}{*}{$\mathrm{SED}^{2}$} & \multicolumn{3}{|c|}{$\begin{array}{l}\text { Statistical significance } \\
(P \text {-value })\end{array}$} \\
\hline & CS0 & $\mathrm{CS} 6$ & CS12 & CS18 & & Linear & Quadratic & Cubic \\
\hline \multicolumn{9}{|l|}{ Solid outflow rate } \\
\hline $\mathrm{k}_{1} \% / \mathrm{h}^{3}$ & 6.9 & 7.4 & 7.1 & 6.7 & 0.4 & 0.49 & 0.17 & 0.65 \\
\hline $\mathrm{k}_{2}, \% / \mathrm{h}^{4}$ & 10.2 & 9.9 & 11.6 & 10.4 & 1.2 & 0.55 & 0.59 & 0.23 \\
\hline Transit time, $\mathrm{h}$ & 8.5 & 8.3 & 8.6 & 8.2 & 0.8 & 0.75 & 0.88 & 0.70 \\
\hline Rumen retention time, $\mathrm{h}$ & 14.4 & 14.0 & 14.2 & 14.9 & 0.6 & 0.46 & 0.22 & 0.95 \\
\hline Mean retention time, $\mathrm{h}$ & 33.1 & 32.6 & 31.9 & 33.3 & 1.2 & 0.99 & 0.27 & 0.59 \\
\hline
\end{tabular}

\footnotetext{
${ }^{1}$ Treatments: $\mathrm{CS} 0=0 \%$ refined cornstarch; $\mathrm{CS} 6=5.9 \%$ refined cornstarch; $\mathrm{CS} 12=11.9 \%$ refined controls; $\mathrm{CS} 18=17.9 \%$ refined cornstarch.

${ }^{2} \mathrm{SED}=$ standard error of difference.

${ }^{3} \mathrm{k}_{1}=$ ruminal rate of passage.

${ }^{4} \mathrm{k}_{2}=$ lower digestive tract rate of passage.
} 
Table 5. Effects of level of refined cornstarch on total trct digestibilities.

\begin{tabular}{llllllllll}
\hline & \multicolumn{4}{c}{ Treatments $^{1}$} & & \multicolumn{3}{c}{ Statistical significance $(P$-value $)$} \\
\cline { 2 - 4 } Digestibilities, \% & CS0 & CS6 & CS12 & CS18 & SED & & Linear & Quadratic & Cubic \\
\hline DM & 60.38 & 60.82 & 61.54 & 60.90 & 2.45 & 0.77 & 0.76 & 0.84 \\
OM & 64.06 & 63.86 & 64.71 & 64.05 & 2.33 & & 0.91 & 0.89 & 0.73 \\
NDF & 41.83 & 35.87 & 39.62 & 33.95 & 4.32 & & 0.16 & 0.96 & 0.18 \\
Starch & 85.12 & 86.38 & 90.24 & 92.36 & 1.86 & 0.001 & 0.75 & 0.47 \\
\hline
\end{tabular}

${ }^{1}$ Treatments: $\mathrm{CS} 0=0 \%$ refined cornstarch; $\mathrm{CS} 6=5.9 \%$ refined cornstarch; $\mathrm{CS} 12=11.9 \%$ refined cornstarch; $\mathrm{CS} 18=17.9 \%$ refined cornstarch.

${ }^{2} \mathrm{SED}=$ standard error of difference.

of refined cornstarch in a cubic manner with rate of digestion being highest for the CS6 diet and lowest for the CS12 diet. Effective rumen digestibility of NDF averaged $38.7 \%$ across diets and was not affected by level of refined cornstarch.

Both total tract digestibility and ruminal digestion kinetics of fiber were unaffected by increasing levels of refined cornstarch in the diet. This indicates that rumen fermentation was not compromised when high levels of refined cornstarch were fed. This is in contrast to Callison et al. (2001), who reported that ruminal NDF digestibility tended to decrease linearly when particle size of corn grain comprising $36.5 \%$ of diet DM was decreased from $4.8 \mathrm{~mm}$ to $1.2 \mathrm{~mm}$.

\section{Microbial Yield}

Urinary purine derivative excretion and microbial $\mathrm{N}$ production estimates are shown in Table 8. Daily excretion of the two purine derivatives, uric acid and allantoin, were not affected by level of refined cornstarch in the diet. Consequently, the calculated absorption of purine derivatives and intestinal flow of microbial $\mathrm{N}$ did not differ between diets. Microbial N supply averaged $371.1 \mathrm{~g} / \mathrm{d}$ which is close to the values reported by Krause et al. (2002b) who also fed diets based on corn grain and alfalfa silage. As mentioned earlier, percentage of milk protein increased in a quadratic matter when level of cornstarch increased, but yield of protein was unaffected by level of refined cornstarch. This is in accordance with the similar microbial $\mathrm{N}$ supplies we observed. Assuming that ruminal starch digestion increased with increasing amounts of refined cornstarch in the diet, one would expect microbial protein yield to increase, unless other factors were limiting microbial protein production. Ruminal $\mathrm{pH}$ was not affected by dietary level of refined cornstarch, so microbial protein yield should not be compromised (Firkins, 1996). Efficiency of microbial $\mathrm{N}$ production, expressed as grams of microbial $\mathrm{N}$ per kilogram of digestible organic matter intake, was not affected by level of refined starch in the diet and averaged $23.2 \mathrm{~g} / \mathrm{kg}$ digestible $\mathrm{OM}$ intake. This efficiency agrees with our previous findings (Krause et al., 2002a; Krause and Combs, 2003).

\section{Chewing Activities}

Chewing activities are shown in Table 9 . Time spent eating decreased linearly from $329 \mathrm{~min} / \mathrm{d}$ to $308 \mathrm{~min} / \mathrm{d}$ when refined cornstarch replaced dry cracked corn in the diet, probably because refined cornstarch was easier to masticate than dry cracked corn. Time spent eating

Table 6. Effects of level of refined cornstarch on alfalfa silage DM digestion kinetics.

\begin{tabular}{lcccccccc}
\hline \multirow{2}{*}{$\begin{array}{l}\text { Dependent } \\
\text { variable }\end{array}$} & \multicolumn{4}{c}{ Treatments $^{1}$} & & & \multicolumn{2}{c}{ Statistical significance $(P$-value $)$} \\
\cline { 2 - 4 } & CS0 & CS6 & CS12 & CS18 & SED $^{2}$ & Linear & Quadratic & Cubic \\
\hline Fraction, \% of DM & & & & & & & & \\
a & 40.3 & 40.2 & 40.3 & 40.2 & 0.2 & 0.55 & 0.82 & 0.58 \\
b & 35.7 & 35.3 & 35.4 & 35.4 & 0.6 & 0.72 & 0.70 & 0.73 \\
c & 24.0 & 24.5 & 24.3 & 24.5 & 0.6 & 0.50 & 0.64 & 0.59 \\
$\mathrm{Lag}, \mathrm{h}$ & 0.69 & 2.20 & 1.30 & 1.10 & 0.68 & 0.88 & 0.07 & 0.15 \\
$\mathrm{k}_{\mathrm{d}}, \% / \mathrm{h}$ & 8.01 & 9.34 & 8.25 & 8.56 & 0.90 & 0.84 & 0.43 & 0.22 \\
$\mathrm{ERD}^{3}, \%$ & 59.1 & 59.7 & 59.0 & 59.7 & 1.0 & 0.71 & 0.91 & 0.38 \\
\hline
\end{tabular}

${ }^{1}$ Treatments: $\mathrm{CS} 0=0 \%$ refined cornstarch; $\mathrm{CS} 6=5.9 \%$ refined cornstarch; $\mathrm{CS} 12=11.9 \%$ refined cornstarch; CS18 $=17.9 \%$ refined cornstarch.

${ }^{2} \mathrm{SED}=$ standard error of difference.

${ }^{3}$ Effective rumen degradability calculated using ruminal rate of passage of chromium mordanted straw $\left(\mathrm{ERD}=\mathrm{a}+\left(\mathrm{b}\left(\mathrm{k}_{\mathrm{d}} /\left(\mathrm{k}_{\mathrm{d}}+\mathrm{k}_{1}\right)\right)\right)\right.$. 
Table 7. Effects of level of refined cornstarch on alfalfa silage NDF digestion kinetics.

\begin{tabular}{|c|c|c|c|c|c|c|c|c|}
\hline \multirow{2}{*}{$\begin{array}{l}\text { Dependent } \\
\text { variable }\end{array}$} & \multicolumn{4}{|c|}{ Treatments $^{1}$} & \multirow[b]{2}{*}{$\mathrm{SED}^{2}$} & \multicolumn{3}{|c|}{ Statistical significance $(P$-value $)$} \\
\hline & CS0 & CS6 & CS12 & CS18 & & Linear & Quadratic & Cubic \\
\hline \multicolumn{9}{|c|}{ Fraction, $\%$ of NDF } \\
\hline $\mathrm{a}$ & 20.4 & 19.5 & 20.5 & 20.8 & 0.9 & 0.46 & 0.33 & 0.36 \\
\hline b & 38.3 & 38.8 & 38.2 & 36.8 & 0.8 & 0.05 & 0.14 & 0.95 \\
\hline $\mathrm{c}$ & 41.4 & 41.6 & 41.2 & 42.7 & 0.7 & 0.08 & 0.19 & 0.29 \\
\hline Lag, h & 2.86 & 3.22 & 3.24 & 3.75 & 0.89 & 0.37 & 0.90 & 0.76 \\
\hline $\mathrm{k}_{\mathrm{d}}, \% / \mathrm{h}$ & 8.38 & 8.79 & 5.34 & 6.69 & 1.57 & 0.12 & 0.64 & 0.07 \\
\hline $\mathrm{ERD}^{3}, \%$ & 39.1 & 38.7 & 37.5 & 39.4 & 1.6 & 0.96 & 0.30 & 0.40 \\
\hline
\end{tabular}

${ }^{1}$ Treatments: $\mathrm{CS} 0=0 \%$ refined cornstarch; $\mathrm{CS} 6=5.9 \%$ refined cornstarch;CS12 $=11.9 \%$ refined cornstarch; $\mathrm{CS} 18=17.9 \%$ refined cornstarch

${ }^{2} \mathrm{SED}=$ standard error of difference.

${ }^{3}$ Effective rumen degradability calculated using ruminal rate of passage of chromium mordanted straw $\left(\mathrm{ERD}=\mathrm{a}+\left(\mathrm{b}\left(\mathrm{k}_{\mathrm{d}} /\left(\mathrm{k}_{\mathrm{d}}+\mathrm{k}_{1}\right)\right)\right)\right.$.

per kg DMI per day tended $(P=0.09)$ to respond quadratically to increasing levels of refined cornstarch with time spent eating/DMI per day being lowest for the CS12 diet. Number of meals per day tended $(P=0.10)$ to increase linearly with increasing level of refined cornstarch in the diet, and the duration of a meal decreased linearly when level of refined cornstarch was increased. Since DMI was not different for cows fed the four diets, the number of meals per kg DMI per day tended to increase linearly with increasing level of refined cornstarch in the diet. This increase in number of meals and decrease in meal size might be in response to the increased fermentability of the diet. Smaller, but more frequent meals would presumably reduce the fermentation acid load associated with a meal. Eating activity was highest during the hour following feeding (Figure 1) and cows spent more time eating during the $12 \mathrm{~h}$ following the morning feeding than during the $12 \mathrm{~h}$ following the evening feeding (194 vs. $124 \mathrm{~min}$ ), despite the fact that equal amounts of feed was allocated at each feeding.
Time spent ruminating per day was not affected by level of refined cornstarch in the diet and averaged 447 min per day. Rumination activity seemed to be equally distributed throughout the $24 \mathrm{~h}$ of the observation period (Figure 1). When level of refined cornstarch was increased, time spent ruminating per $\mathrm{kg}$ NDF intake per day tended $(P=0.09)$ to respond quadratically, with time spent ruminating per $\mathrm{kg}$ NDF intake per day being lower for the CS12 diet than for the other diets. This is in contrast to our earlier studies where time spent ruminating per $\mathrm{kg}$ of NDF intake increased with increasing fermentability of the diet (Krause et al., 2002b and Krause and Combs, 2003). Number of rumination periods per day and the duration of the rumination periods tended $(P=0.07)$ to respond to level of pure starch in the diet in a cubic manner with number of periods and duration of periods being highest for the two intermediate diets, CS6 and CS12.

Total time spent chewing tended $(P=0.08)$ to decrease linearly from 784 to $754 \mathrm{~min} / \mathrm{d}$ when refined cornstarch replaced dry cracked corn. Because DMI was

Table 8. Effects of level of refined cornstarch on purine derivative excretion.

\begin{tabular}{|c|c|c|c|c|c|c|c|c|}
\hline \multirow{2}{*}{$\begin{array}{l}\text { Dependent } \\
\text { variable }\end{array}$} & \multicolumn{4}{|c|}{ Treatments $^{1}$} & \multirow[b]{2}{*}{$\mathrm{SED}^{2}$} & \multicolumn{3}{|c|}{$\begin{array}{l}\text { Statistical significance } \\
(P \text {-value })\end{array}$} \\
\hline & CS0 & CS6 & CS12 & CS18 & & Linear & Quadratic & Cubic \\
\hline \multicolumn{9}{|l|}{ Urinary excretion } \\
\hline Uric acid, mmol/d & 52.3 & 53.4 & 51.5 & 53.7 & 3.4 & 0.84 & 0.83 & 0.48 \\
\hline Allantoin, $\mathrm{mmol} / \mathrm{d}$ & 512.9 & 518.1 & 490.5 & 540.8 & 29.1 & 0.54 & 0.28 & 0.25 \\
\hline Total, $\mathrm{mmol} / \mathrm{d}$ & 565.6 & 572.0 & 541.6 & 594.2 & 31.8 & 0.58 & 0.31 & 0.25 \\
\hline Absorption $^{3}, \mathrm{mmol} / \mathrm{d}$ & 507.2 & 515.7 & 478.5 & 540.5 & 37.9 & 0.59 & 0.31 & 0.24 \\
\hline Microbial N supply ${ }^{3}$, g/d & 368.7 & 374.9 & 347.9 & 392.9 & 27.2 & 0.59 & 0.31 & 0.24 \\
\hline g microbial N/kg DOMI ${ }^{4}, \mathrm{~g} / \mathrm{kg}$ & 23.09 & 22.93 & 21.95 & 24.69 & 1.79 & 0.48 & 0.26 & 0.43 \\
\hline
\end{tabular}

\footnotetext{
${ }^{1}$ Treatments: $\mathrm{CS} 0=0 \%$ refined cornstarch; $\mathrm{CS} 6=5.9 \%$ refined cornstarch; $\mathrm{CS} 12=11.9 \%$ refined cornstarch; CS18 $=17.9 \%$ refined cornstarch.

${ }^{2} \mathrm{SED}=$ standard error of difference.

${ }^{3}$ Calculations based on equation from Chen and Gomes (1992).

${ }^{4} \mathrm{DOMI}=$ digestible organic matter intake.
} 
Table 9. Effects of level of refined cornstarch on chewing behavior.

\begin{tabular}{|c|c|c|c|c|c|c|c|c|}
\hline \multirow{2}{*}{$\begin{array}{l}\text { Dependent } \\
\text { variable }\end{array}$} & \multicolumn{4}{|c|}{ Treatments $^{1}$} & \multirow[b]{2}{*}{$\mathrm{SED}^{2}$} & \multicolumn{3}{|c|}{$\begin{array}{l}\text { Statistical significance } \\
\quad(P \text {-value })\end{array}$} \\
\hline & CS0 & CS6 & CS12 & CS18 & & Linear & Quadratic & Cubic \\
\hline \multicolumn{9}{|l|}{ Eating } \\
\hline Time, $\mathrm{min} / \mathrm{d}$ & 329 & 322 & 311 & 308 & 11 & 0.05 & 0.75 & 0.73 \\
\hline Time/DMI per $\mathrm{d}, \mathrm{min} / \mathrm{kg}$ & 12.6 & 12.0 & 11.6 & 12.3 & 0.6 & 0.54 & 0.09 & 0.61 \\
\hline Meals, number/d & 11.8 & 12.1 & 12.6 & 12.8 & 0.6 & 0.10 & 0.89 & 0.71 \\
\hline Duration of meal, min & 32.5 & 29.8 & 29.3 & 28.7 & 1.9 & 0.05 & 0.42 & 0.68 \\
\hline Meals/DMI per $\mathrm{d}, \mathrm{kg}^{-1}$ & 0.46 & 0.45 & 0.47 & 0.51 & 0.03 & 0.08 & 0.26 & 0.87 \\
\hline \multicolumn{9}{|l|}{ Rumination } \\
\hline Time, $\min / \mathrm{d}$ & 456 & 446 & 440 & 445 & 14 & 0.39 & 0.46 & 0.86 \\
\hline Time/NDF intake per $\mathrm{d}, \mathrm{min} / \mathrm{kg}$ & 63 & 63 & 59 & 65 & 3 & 0.81 & 0.09 & 0.12 \\
\hline Rumination periods, number/d & 27.4 & 29.9 & 26.9 & 27.7 & 1.6 & 0.68 & 0.46 & 0.07 \\
\hline Chewing time, $\mathrm{min} / \mathrm{d}$ & 784 & 768 & 751 & 754 & 19 & 0.08 & 0.48 & 0.74 \\
\hline Time/DMI per $\mathrm{d}, \mathrm{min} / \mathrm{kg}$ & 30.2 & 28.6 & 28.1 & 30.2 & 1.1 & 0.91 & 0.02 & 0.68 \\
\hline
\end{tabular}

${ }^{1}$ Treatments: $\mathrm{CS} 0=0 \%$ refined cornstarch $; \mathrm{CS} 6=5.9 \%$ refined cornstarch $; \mathrm{CS} 12=11.9 \%$ refined cornstarch; $\mathrm{CS} 18=17.9 \%$ refined cornstarch.

${ }^{2} \mathrm{SED}=$ standard error of difference.

numerically higher for the CS6 and CS12 diets, time spent chewing per kg DMI per day decreased quadratically when level of refined cornstarch increased. This increase in time spent chewing per kg of DMI was probably not a result of the level of refined cornstarch in the diet, but simply a result of the higher DMI. Cows tend to decrease time spent chewing per kg DMI when DMI increases (Beauchemin, 1991).

\section{Ruminal $\mathrm{pH}$ and VFA}

Concentrations and percentages of total and individual VFA are shown in Table 10. Concentration of total VFA was not affected by level of refined cornstarch in the diet and averaged $131.2 \mathrm{mM}$. An increase in total VFA with increasing levels of refined cornstarch in the diet was expected since DMI was similar across diets

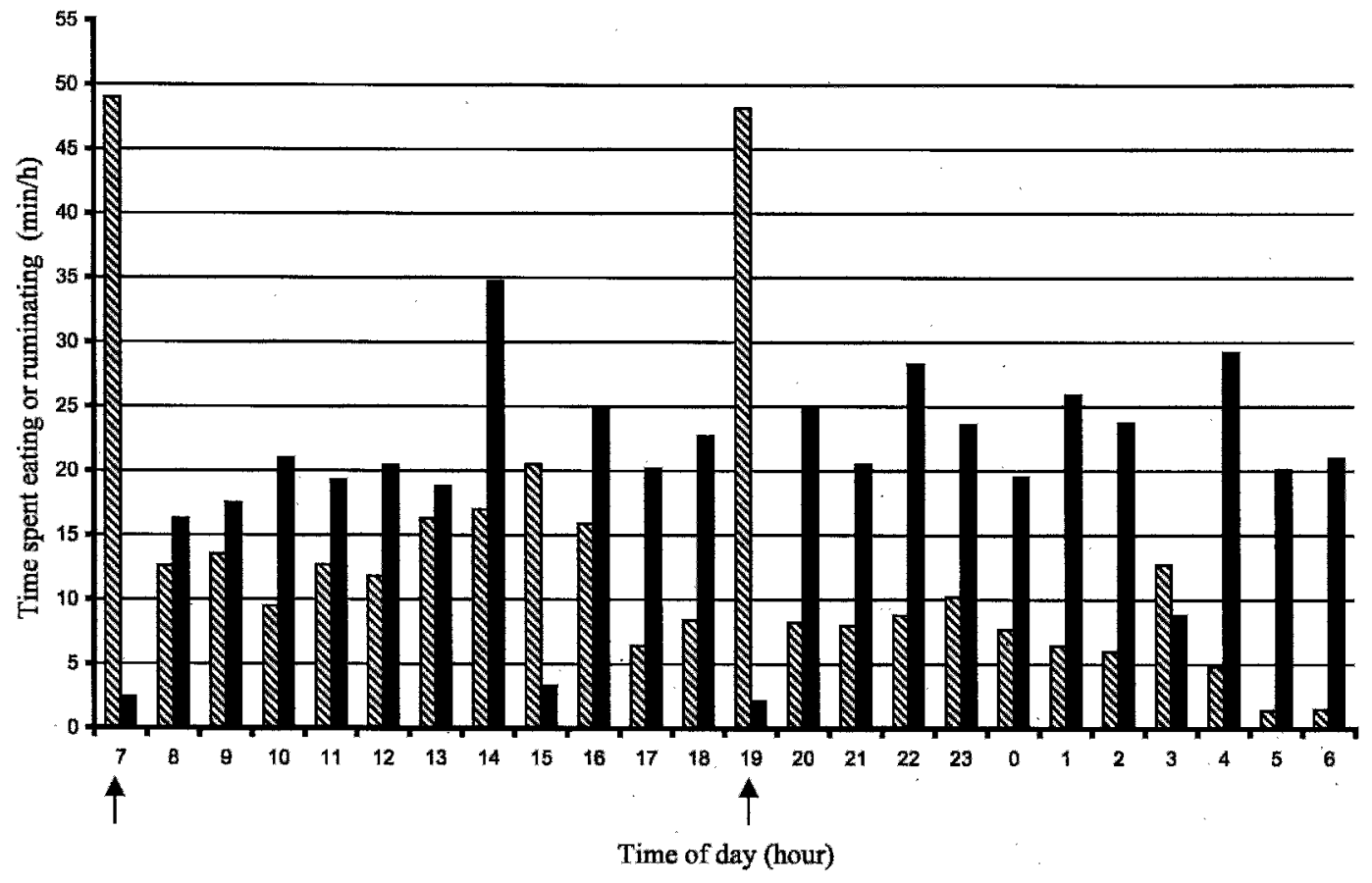

Figure 1. Daily eating and rumination activity averaged across all diets. Arrows indicate time of feeding. Eating: striped bars, Rumination: solid bars. 
Table 10. Effects of level of refined cornstarch on ruminal VFA concentrations.

\begin{tabular}{|c|c|c|c|c|c|c|c|c|}
\hline \multirow{2}{*}{$\begin{array}{l}\text { Dependent } \\
\text { variable }\end{array}$} & \multicolumn{4}{|c|}{ Treatments $^{1}$} & \multirow[b]{2}{*}{ SED } & \multicolumn{3}{|c|}{$\begin{array}{l}\text { Statistical significance } \\
(P \text {-value })\end{array}$} \\
\hline & CS0 & CS6 & CS12 & CS18 & & Linear & Quadratic & Cubic \\
\hline \multicolumn{9}{|l|}{ VFAs, m $M$} \\
\hline Total & 130.8 & 131.2 & 131.5 & 131.3 & 4.3 & 0.89 & 0.93 & 0.98 \\
\hline Acetate & 73.2 & 72.1 & 71.5 & 69.3 & 2.1 & 0.08 & 0.75 & 0.76 \\
\hline Propionate & 26.9 & 28.0 & 31.1 & 33.7 & 1.9 & 0.001 & 0.58 & 0.67 \\
\hline Butyrate & 20.4 & 21.0 & 18.6 & 18.0 & 1.0 & 0.008 & 0.45 & 0.17 \\
\hline Acetate:Propionate & 2.84 & 2.72 & 2.38 & 2.24 & 0.18 & 0.002 & 0.93 & 0.49 \\
\hline \multicolumn{9}{|c|}{$\mathrm{VFA},{ }^{3} \mathrm{mmol} / \mathrm{mmol}$ total } \\
\hline Acetate & 56.4 & 54.9 & 54.7 & 53.4 & 1.3 & 0.03 & 0.85 & 0.60 \\
\hline Propionate & 20.5 & 21.4 & 28.8 & 25.4 & 1.3 & 0.001 & 0.71 & 0.64 \\
\hline Butyrate & 15.7 & 15.9 & 14.0 & 13.7 & 0.6 & 0.001 & 0.51 & 0.06 \\
\hline
\end{tabular}

${ }^{1}$ Treatments: $\mathrm{CS} 0=0 \%$ refined cornstarch; $\mathrm{CS} 6=5.9 \%$ refined cornstarch; $\mathrm{CS} 12=11.9 \%$ refined cornstarch; CS18 $=17.9 \%$ refined cornstarch .

${ }^{2} \mathrm{SED}=$ standard error ofdifference.

${ }^{3}$ VFA percentage expressed as millimoles per $100 \mathrm{mmol}$ of total VFA.

and replacing dry cracked corn with refined cornstarch was assumed to increase the ruminal fermentability of the diet. Replacing dry cracked corn with refined cornstarch did alter the pattern of VFA. Both concentration and percentage of acetate decreased linearly when refined cornstarch was increased and concentration and percentage of propionate increased linearly. This resulted in a linear decrease in the acetate:propionate ratio as refined cornstarch replaced dry cracked corn. The change observed in acetate and propionate concentrations indicates a shift in ruminal fermentation pattern consistent with what would be expected when carbohydrate fermentability is increased. Also, the changes in acetate to propionate ratio are in accordance with the trend towards a decrease in milk fat percentage observed when the level of refined cornstarch was increased. Concentration and percentage of butyrate decreased linearly when the level of refined cornstarch was increased.

Ruminal $\mathrm{pH}$ data are presented in Table 11. In contrast to what we have found in previous experiments investigating dietary effects on ruminal $\mathrm{pH}$ (Krause et al., 2002b; Krause and Combs, 2002), we found that ruminal $\mathrm{pH}$ differed across the $3 \mathrm{~d}$ of measurements carried out in the current experiment $(P=0.007)$. On $\mathrm{d} 1,2$, and $3, \mathrm{pH}$ averaged 5.93, 6.06, and 5.97, respectively. Ruminal $\mathrm{pH}$ was not affected by feeding (morning vs. evening; $P=0.58$ : data not shown). No interactions between day and dietary treatments on $\mathrm{pH}$ were observed. Diurnal fluctuations in ruminal $\mathrm{pH}$ for the four diets are shown in Figure 2. All four diets resulted in similar biphasic diurnal patterns. Ruminal $\mathrm{pH}$ declined immediately after feeding and subsequently started to increase again. Ruminal $\mathrm{pH}$ was highest at the time before the morning feeding resulting in a larger peak in $\mathrm{pH}$ associated with the morning feeding than with the evening feeding. The pattern in ruminal $\mathrm{pH}$ differed between the two daily feedings as shown by an interaction between feeding and hours post-feeding $(P$ $<0.0001$; data not shown). The pattern associated with the evening feeding was characterized by a lower initial $\mathrm{pH}$ than that for the morning feeding (5.97 vs. 6.14), but a higher $\mathrm{pH}$ at the time of the next feeding than for the morning feeding (Figure 3). Also, nadir after

Table 11. Effects of level of refined cornstarch on ruminal $\mathrm{pH}$.

\begin{tabular}{|c|c|c|c|c|c|c|c|c|}
\hline \multirow{2}{*}{$\begin{array}{l}\text { Dependent } \\
\text { variable }\end{array}$} & \multicolumn{4}{|c|}{ Treatments $^{1}$} & \multirow[b]{2}{*}{$\mathrm{SED}^{2}$} & \multicolumn{3}{|c|}{$\begin{array}{l}\text { Statistical significance } \\
\quad(P \text {-value })\end{array}$} \\
\hline & CS0 & CS6 & CS12 & CS18 & & Linear & Quadratic & Cubic \\
\hline Mean ruminal $\mathrm{pH}$ & 5.98 & 5.97 & 6.00 & 5.93 & 0.12 & 0.75 & 0.71 & 0.71 \\
\hline Lowest daily pH & 5.50 & 5.44 & 5.48 & 5.38 & 0.13 & 0.44 & 0.84 & 0.59 \\
\hline Hours post-feeding for lowest $\mathrm{pH}, \mathrm{h}$ & 6.1 & 5.6 & 4.4 & 5.3 & 0.9 & 0.20 & 0.28 & 0.33 \\
\hline Hours below pH $5.8, \mathrm{~h} / \mathrm{d}$ & 8.1 & 7.7 & 8.0 & 9.5 & 2.7 & 0.58 & 0.60 & 0.93 \\
\hline Area below pH $5.8, \mathrm{~h} \times \mathrm{pH}$ units $/ \mathrm{d}$ & 2.6 & 2.5 & 2.9 & 3.5 & 1.3 & 0.46 & 0.76 & 0.93 \\
\hline
\end{tabular}

${ }^{1}$ Treatments: $\mathrm{CS} 0=0 \%$ refined cornstarch; $\mathrm{CS} 6=5.9 \%$ refined cornstarch; $\mathrm{CS} 12=11.9 \%$ refined cornstarch; CS18 $=17.9 \%$ refined cornstarch .

${ }^{2} \mathrm{SED}=$ standard error of difference. 


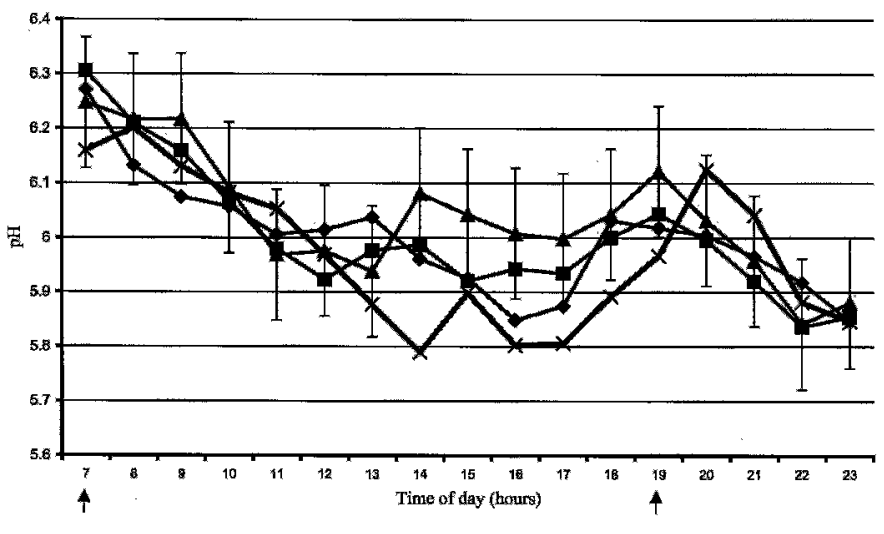

Figure 2. Diurnal fluctuations in ruminal $\mathrm{pH}$ for diets differing in level of refined cornstarch. Arrows indicate feedings. CS0: 口; CS12: $\mathbf{\Delta}$; CS18: $\times$. Treatments: CS0 $=0 \%$ refined cornstarch; CS6 $=5.9 \%$ refined cornstarch CS12 $=11.9 \%$ refined cornstarch; CS18 $=$ $17.9 \%$ refined cornstarch.

feeding was reached $4.4 \mathrm{~h}$ post-feeding in the evening, but $6.3 \mathrm{~h}$ post-feeding in the morning $(\mathrm{P}=0.0011$; data not shown). This difference between the two feedings in postprandial $\mathrm{pH}$ pattern has been observed before (Krause et al., 2002b, Krause and Combs, 2003; Nocek and Braund, 1985), and is probably caused by the diurnal pattern in eating and rumination behavior (see Figure 1). Cows spent more time eating during the hours between the morning and the evening feeding than between the evening and the morning feeding (194 vs. $124 \mathrm{~min}$ ), indicating a higher DM intake during the day hours than during the night. Time spent ruminating was fairly similar for the hours between the morning and evening feeding (222 $\mathrm{min})$ and for the hours between the evening and morning feeding (248 min),

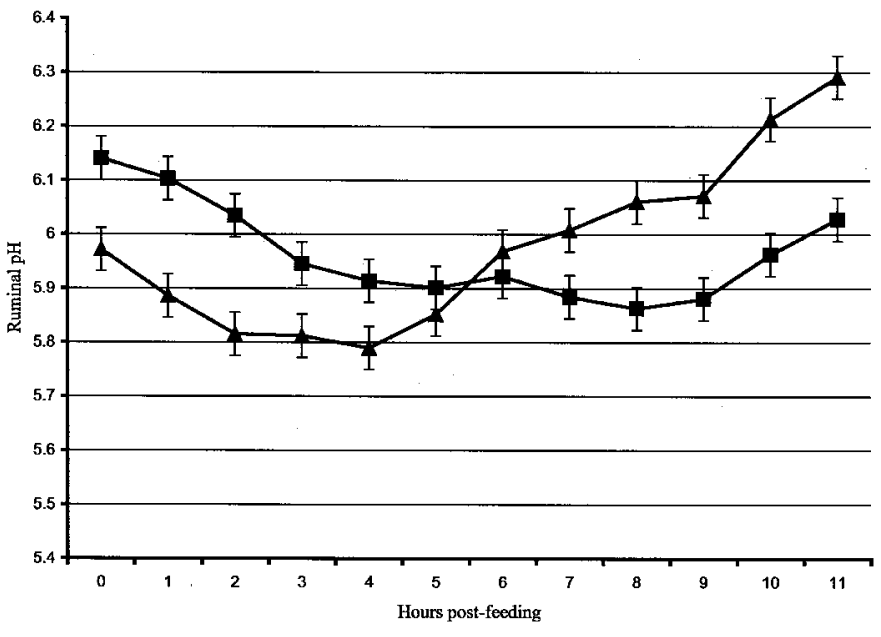

Figure 3. Effect of feeding (morning vs. evening) on ruminal $\mathrm{pH}$ pattern. Morning feeding: $\mathbf{a}$; Evening feeding: $\boldsymbol{\Delta}$. probably resulting in similar amounts of buffer being secreted during the times between the two feedings.

None of the ruminal $\mathrm{pH}$ variables were affected by level of refined cornstarch in the diet. Mean ruminal $\mathrm{pH}$ averaged across diets was higher than the values for coarse forage diets we have found previously (5.97 vs. 5.82; Krause and Combs, 2003). These results indicate that the ruminal fermentability of refined cornstarch was not as extensive as assumed. In previous studies we have consistently found that increasing ruminal fermentability of the carbohydrates by replacing dry cracked corn with ground high moisture corn decreases mean ruminal $\mathrm{pH}$ and increases time and area below pH 5.8 (Krause et al., 2002b and Krause and Combs, 2003). Hours and area below pH 5.8 was numerically greater for the CS18 diet than for the other diets. The very coarse alfalfa silage fed in this experiment caused cows to spend $12.7 \mathrm{~h}$ per d chewing, providing saliva and buffers. The combination of this buffering capacity and the lower than expected ruminal fermentability of refined cornstarch probably only resulted in minor changes in ruminal fermentation and $\mathrm{pH}$ when dietary level of refined cornstarch was increased.

\section{CONCLUSIONS}

Feeding up to $17.9 \%$ of $\mathrm{DM}$ as refined cornstarch as part of diets with around 30\% dietary starch did not affect DMI or lactation performance of midlactation cows. Milk fat percentage tended to show a negative linear relationship with level of refined cornstarch in the diet, whereas milk protein percentage increased in a quadratic manner with increasing level of refined cornstarch. Yield of milk fat and milk protein was unaffected by source of starch and so was yield of energy corrected milk.

Ruminal and total tract digestibility of fiber was not negatively affected when refined cornstarch replaced starch from dry cracked corn. Total tract digestibility of starch increased linearly with increasing levels of refined cornstarch in the diet, but microbial yield of protein was unaffected by level of refined cornstarch.

Mean ruminal $\mathrm{pH}$ did not decrease with increasing levels of refined cornstarch in the diet and neither did the diurnal $\mathrm{pH}$ pattern or hours spend and area spent below $\mathrm{pH}$ 5.8. However, rumen fermentation pattern changed when refined cornstarch replaced dry cracked corn. Concentration and proportion of acetate decreased linearly, whereas propionate concentration and proportion increased linearly when level of refined cornstarch was increased.

Based on the results from this study it can be concluded that up to $57 \%$ of the total dietary starch can be provided as refined cornstarch without compromising 
rumen fermentation and performance of midlactation dairy cows when fed alfalfa silage based diets, which provided plenty of physically effective fiber.

\section{REFERENCES}

Aldrich, J. M., L. D. Muller, G. A. Varga, and L. C. Griel, Jr. 1993. Nonstructural carbohydrate and protein effects on rumen fermentation, nutrient flow, and performance of dairy cows. J. Dairy Sci. 76:1091-1105.

American National Standards Institute. 1988. Method of determining and expressing particle size of chopped forage materials by screening. ASAE S424, ASAE, St. Joseph, MI.

American National Standards Institute. 1995. Method of determining and expressing fineness of feed material by sieving. ASAE Standards 1995 p. 461, ASAE, St. Joseph, MI.

Association of Official Analytical Chemists. 1990. Official Methods of Analysis. Vol. I. 15th ed. AOAC, Arlington, VA.

Bal, M. A., R. D. Shaver, A. G. Jirovec, K. J. Shinners, and J. G. Coors. 2000. Crop processing and chop length of corn silage: Effects on intake, digestion, and milk production by dairy cows. J. Dairy Sci. 83:1264-1273.

Beauchemin, K. A. 1991. Ingestion and mastication of feed by dairy cattle. Pages 439-463 in Dairy nutrition management. C.J. Sniffen and T.H. Herdt, ed. The veterinary clinics of North America. Food animal practice. Vol. 7(2).

Britton, R. A., and R. A. Stock. 1987. Acidosis, rate of starch digestion and intake. Pages 125-137 in Okla. Agric. Exp. Stn. MP-121.

Callison, S. L., J. L. Firkins, M. L. Eastridge, and B. L. Hull. 2001. Site of nutrient digestion by dairy cows fed corn of different particle sizes or steam-rolled. J. Dairy Sci. 84:1458-1467.

Chen, X. B., and M. J. Gomes. 1992. Estimation of microbial protein supply to sheep and cattle based on urinary excretion of purine derivatives-an overview of the technical details. International Feed Resources Unit, Rowett Research Institute, Bucksburn, Aberdeen, AB2 9SB, UK. Occasional Publication.

Cherney, D. J .R., J. A. Patterson, and R. P. Lemenager. 1990. Influence of in situ bag rinsing technique on determination of drymatter disappearance. J. Dairy Sci. 73:391-397.

Combs, D. K., and L. D. Satter. 1992. Determination of markers in digesta and feces by direct-current plasma emission-spectroscopy. J. Dairy. Sci. 75:2176-2183.

Crocker, L. M., E. J. DePeters, J. G. Fadel, H. Perez-Monti, S. J. Taylor, J. A. Wyckoff, and R. A. Zinn. 1998. Influence of processed corn grain in diets of dairy cows on digestion of nutrients and milk production. J. Dairy Sci. 81:2394-2407.

Firkins, J. L. 1996. Maximizing microbial protein synthesis in the rumen. J. Nutr. 126:1347S-1354S.

Firkins, J. L., M. L. Eastridge, N. R. St-Pierre, and S. M. Noftsger. 2001. Effects of grain variability and processing on starch utilization by lactating dairy cattle. J. Anim. Sci. 79(E. Suppl.):E218E238.

Goering, H. K., and P. J. Van Soest. 1970. Forage Fiber Analyses. (Apparatus, Reagents, Procedures, and Some Applications). Agric. Handbook No. 379. ARS-USDA, Washington, DC.

Grovum, W. L., and V. J. Williams. 1973. Rate of passage of digesta in sheep. 4. Passage of marker through alimentary tract and the biological relevance of rate-constants derived from the changes in concentration of marker in faeces. Br. J. Nutr. 30:313-329.

Hartnell, G. F., and L. D. Satter. 1979. Determination of rumen fill, retention time and ruminal turnover rates of ingesta at different stages of lactation in dairy cows. J. Anim. Sci. 48:381-392.

Knowlton, K. F., B. P. Glenn, and R. A. Erdman. 1998. Performance, ruminal fermentation, and site of starch digestion in early lactation cows fed corn grain harvested and processed differently. J. Dairy Sci. 81:1972-1984.
Knowlton, K. F., M. S. Allen, and P. S. Erickson. 1996. Lasalocid and particle size of corn grain for dairy cows in early lactation. 2. Effect on ruminal measurements and feeding behavior. J. Dairy Sci. 79:557-574.

Krause, K. M., D. K. Combs, and K. A. Beauchemin. 2002a. Effects of forage particle size and grain fermentability in midlactaion cows. I. Milk production and diet digestibility. J. Dairy Sci. 85:1936-1946.

Krause, K. M., D. K. Combs and K. A. Beauchemin. 2002b. Effects of forage particle size and grain fermentability in midlactation cows. II. Ruminal $\mathrm{pH}$ and chewing activity. J. Dairy Sci. 85:1947-1957.

Krause, K.M., and D.K. Combs. 2003. Effects of forage particle size, forage source and grain fermentability on performance and ruminal $\mathrm{pH}$ in midlactation cows. J. Dairy Sci. (accepted for publication).

McAllister, T. A., L. M. Rode, D. J. Major, K.-J. Cheng, and J. G. Buchanan-Smith. 1990. Effect of ruminal microbial colonization on cereal grain digestion. Can. J. Anim. Sci. 70:571-579.

McCarthy, R. D., Jr., T. H. Klusmeyer, J. L. Vicini, J. H. Clark, and D. R. Nelson. 1989. Effects of source of protein and carbohydrate on ruminal fermentation and passage of nutrients to the small intestine of lactating cows. J. Dairy Sci. 72:2002-2016.

McDonald, I. 1981. A revised model for the estimation of protein degradability in the rumen. J. Agric. Sci. 96:251-252.

Mertens, D. R. 1999. Variation in NDF results with modifications of the filter bag method. National Forage testing Association, Technical Sessions papers and Committee Reports to the Board and Membership, June 1999, Topeka, Kansas.

Moore, J. A., M. H. Poore, T. P. Eck, R. S. Swingle, J. T. Huber, and M. J. Arana. 1992. Sorghum grain processing and buffer addition for early lactation cows. J. Dairy Sci. 75:3465-3472.

Mould, F. L., E. R. Ørskov, and S. O. Mann. 1983. Associative effects of mixed feeds.I. Effects of type and level of supplementation and the influence of the rumen fluid $\mathrm{pH}$ on cellolysis in vivo and dry matter digestion of various roughages. Anim. Feed Sci. Technol. 10:15-30.

National Research Council. 1989. Nutrient Requirements of Dairy Cattle. 6th rev. ed. National Academy Press, Washington DC.

National Research Council. 2001. Nutrient requirements of dairy cattle. 7th rev. ed. National Academy Press, Washington, DC.

Nocek, J. E., and D. G. Braund. 1985. Effect of feeding frequency on diurnal dry matter and water consumption, liquid dilution rate, and milk yield in first lactation. J. Dairy Sci. 68:2238-2247.

Nocek, J. E., and S. Tamminga. 1991. Site of digestion of starch in the gastrointestinal tract of dairy cows and its effect on milk yield and composition. J. Dairy Sci. 74:3598-3229.

SAS User's Guide: Statistics. Version 7 Edition. 1998. SAS Inst., Inc., Cary, NC.

Strobel, H. J., and J. B. Russell. 1986. Effect of pH and energy spilling on bacterial protein synthesis by carbohydrate-limited cultures of mixed rumen bacteria. J. Dairy Sci. 69:2941-2947.

Tyrrell, H. F., and J. T. Reid. 1965. Prediction of the energy value of cows milk. J. Dairy Sci. 48:1215-1223.

Udén, P., P. E. Colucci, and P. J. van Soest. 1980. Investigation of chromium, cerium and cobalt as digesta flow markers in rate of passage studies. J. Sci. Food Agric. 31:625-632.

Vagnoni, D. B., G. A. Broderick, M. K. Clayton, and R. D. Hatfield. 1997. Excretion of purine derivatives by Holstein cows abomasally infused with incremental amounts of purines. J. Dairy Sci. 80:1695-1702.

van Vuuren, A. M, A. Klop, C. J. van der Koelen, and H. de Visser. 1999. Starch and stage of maturity of grass silage: site of digestion and intestinal nutrient supply in dairy cows. J. Dairy Sci. 82:143-152

Wangsness, P. J., L. E. Chase, A. D. Peterson, T. G. Hartsock, D. J. Kellmel, and B. R. Baumgardt. 1976. System for monitoring feeding behavior of sheep. J. Anim. Sci. 42:1544-1549. 